\title{
Enfranchising Foreign Residents in Democracy and Dictatorship in Chile
}

\author{
Victoria Finn \\ Universidad Diego Portales \\ Leiden University \\ Draft presented at the APSA Annual Meeting \& Exhibition, \\ “Democracy, Difference, and Destabilization”, September 9-13, 2020. \\ Contact the author for an updated version: \\ VickiJFinn@gmail.com
}

\begin{abstract}
Fear, terror, and control are words used to discuss dictatorship, whereas inclusion, participation, and freedom parallel democracy. While survival of social and political rights is unusual in dictatorship, granting more voting rights is bizarre, especially at a time without elections. An early adopter of locallevel immigrant suffrage in 1925, Chile expanded foreign residents' rights to national-level elections in the 1980 Constitution. How and why did a military dictatorship expand immigrant voting rights? Building on existent literature and data, I conduct textual analysis of the 1974 Ortúzar Commission during constitutional revision, complemented with historical archival research in Chile. I argue that political co-optation, control, and the immigrant population size fail to explain immigrant voting rights' survival and extension through shifting (non)democratic regimes. This extreme case of immigrant enfranchisement in Chile reveals the importance of both path dependence and elites' divided opinions on optional versus obligatory voting for foreign residents versus nationals.
\end{abstract}

Keywords enfranchisement, immigrant voting rights, suffrage rights, foreign residents, political incorporation, nondemocracy 


\section{Introduction}

Countries offering extensive migrant suffrage rights allow foreign residents and nonresident nationals to affect the decision-making process. ${ }^{1}$ Although granting voting rights to migrants may appear to be a contemporary phenomenon full of democratic ideals, it is a continuation of a longstanding process of defining who belongs in the demos-and by default, who it excludes. This inclusion-exclusion debate has included topics of race, gender, property, morals, intellect, physical wellness, as well as residence and citizenship (as nationality) (Caramani and Grotz 2015). Enfranchising nonresident emigrants abroad questions residence as a requirement, whereas extending suffrage to foreign residents means adopting nationality is no longer required for voting. ${ }^{2}$ An important factor within domestic contexts is that immigrant enfranchisement and suffrage expansion have occurred during various political regime types, as well as survived through nondemocratic periods.

Latin American countries offer widespread migrant suffrage rights, while the region has also had large shifts in political regimes, fluctuating numerous times between democracy and authoritarianism (Escobar 2015; GLOBALCIT 2019). Chile and Ecuador both offer suffrage to nonresident nationals abroad, although Chile was a regional latecomer, doing so for the first time in 2017. Both countries also offer adult foreign residents voting rights after living in the country for five years. Uruguay heightens barriers to obtaining suffrage rights since the Electoral Court issues voter registration only to foreign residents who can prove all of the following: exhibit good behavior (i.e., no criminal record), own property or capital in Uruguay, have an occupation or profession, have formed a family in Uruguay, as well as have been a resident for the last 15 years (Stuhldreher 2012; Article 78, National Constitution). The three countries have various tracks in terms of migrant enfranchisement and survival of rights through various political regime shifts.

\footnotetext{
${ }^{1}$ Throughout this article, I use "foreign residents" synonymously with "immigrants" to capture nonnaturalized foreigners living in Chile; I also use "nonresident nationals" interchangeably with "emigrants", although the former is a larger group (since some Chileans abroad hold the nationality, without ever having lived in Chile-e.g., having been born to Chilean parent).

${ }^{2}$ Nonresident voting is also called external, extraterritorial, or emigrant voting or simply voting from abroad. Foreign residents are also called aliens, foreigners, denizens, or immigrants. I use 'migrants' to refer to both immigrants and emigrants.
} 
Before authoritarian experiences in Chile, the country had extended some foreign residents suffrage in local elections in 1925 during 'democracy': Article 104 of the 1925 Constitution allowed literate foreign-born men over the age of 21 to vote in municipal elections, after meeting a 5-year residence requirement in Chile. I use democracy in quotes since the type of government during Arturo Alessandri Palma (twice President) differed from modern liberal democracy, especially during his first administration. After a competitive presidential election in 1920-but that was marked by fraudulent practices by both main candidates (Millar 1981)—scholars have classified Alessandri as a populist leader given his anti-oligarchical rhetoric aimed at connecting with the 'masses' (Hawkins and Rovira 2017). According to various democracy indexes, there was a drop_-but not a collapse_of democracy between 1925 and 1932, then a steady growth, which then collapsed 1970 to 1990 during dictatorship.

Foreign resident voting rights were then extended to national-level elections in Chile's 1980 Constitution, established during military dictatorship (Historia de la Ley 2005; Escobar 2015, 2017). Also during authoritarianism, Uruguay provided multilevel suffrage rights to foreign residents in 1934, then these rights survived a return to democracy and another later decade of dictatorship starting in the early 1970s (Escobar 2015). While both early adopters, Chile had low immigrant stocks during this period (see Figure 1), whereas Uruguay had one of the highest stocks in the continent, along with Argentina and Brazil (Escobar 2015). Comparatively, after authoritarianism in the late 1970s, Ecuador was a latecomer since it enshrined multilevel foreign resident suffrage during democracy in the 2008 Constitution. These rights have survived an authoritarian period thereafter, 2010-2011.

The present analysis finds new evidence regarding the reasons why states politically incorporate foreign residents, and the processes behind such actions. By recognizing that Chile expanded national-level immigrant voting rights during authoritarianism, this article provides two main contributions. First is the evident longevity of historical notions of who is part of the demosevidencing Brubaker's (1992) insights and supporting Earnest's (2008) findings-which holds true even when a country faces different ideologies and drastic changes in political power. Second is the durability of migrant suffrage rights to survive and expand through political regime shifts.

The following section fits the present analysis into the migrant enfranchisement debate. Thereafter I explain my data and method of analysis, then examine Chile's process of extending voting rights to foreign residents in multilevel elections. The conclusion highlights the relevance these new findings contribute to the literature on why some states have decided to indiscriminately include all foreign residents into the demos. 


\section{Why and Where Enfranchise Migrants? A Plethora of Scenarios}

Extending suffrage rights to migrants is a growing worldwide trend (Arrighi and Bauböck 2017). Nonresident voting from abroad is present in over 100 countries in some form (Caramani and Grotz 2015: 805) and foreign resident voting occurs in more than 50 (Escobar 2015). As Palop-García and Pedroza (2018) define, three steps exist to enfranchise emigrants: passing, regulating, then applying legislation. The steps mean a country enshrines suffrage rights in law, then creates regulatory steps to access the right to vote (e.g., electoral laws), then implements it, marked by the first time the new group of migrant voters can cast a ballot in an election. The same steps hold true for immigrant enfranchisement.

Despite its global reach, migrant enfranchisement is a heterogeneous trend: it varies depending on discussing versus enacting rights, distinguishing between local- and national-level elections, and from deciding to include all or only select migrants in the demos (Pedroza 2015). State regulations and multistep processes form barriers that control and constrain the number of foreign residents who have the chance to fully participate in the destination country's society, in an economic, social, and political sense (Finn 2019). Specifically, states decide to what extent to include which migrants into the political community.

Studies have pinpointed many reasons why countries enfranchise migrants, under which types of government, and how quickly or slowly they have adopted and implemented such rights. Normative reasons have revolved around enfranchising those who are subject to a government and its laws, those who are affected by a government's decisions, or those who are stakeholders (e.g., Whelan 1983; Bauböck 2005, 2015; Shapiro 2003; López-Guerra 2005; Earnest 2006; Owen 2012). Beckman (2008: 31) also contributes pertinent normative work on typical, yet debated, exclusions to 'universal' suffrage such for minors, felons, the intellectually disabled, and migrants.

Typical reasons for enfranchising foreign residents generally involve, a) states' attempts to politically integrate immigrants, b) having shared an imperial past, c) previously living under the same political authority, or d) a cultural or linguistic affinity (Bauböck 2005: 685; also see Pedroza 2019). Alternatively, "immigrant political incorporation most often takes place when the dominant political coalition is under stress and... [tries] to reorganize it by bringing new actors in" (Mollenkopf 2013: 112). Additionally, immigration size is cited as a reason for extending (or withholding) foreign residents' suffrage rights (e.g., Caramani and Grotz 2015) or external emigrant enfranchisement 
(Lafleur 2015). Yet, these reasons do not hold in the cases of offering additional migrant rights in Chile or Ecuador (Echeverría 2015a, 2015b; Escobar 2015: 932).

Regarding elections for the origin country, Owen (2012: 641, 659) highlights the arbitrary demos problem, which is about who determines if emigrants gain voting rights, and on what terms. Migrant enfranchisement is a multistep, multilevel process involving many actors, national and historical factors, as well as constitutional law and electoral reforms. Since nonresident nationals live in various other countries, their experiences vary, such as how far they live from the origin country and the political institutions and systems with which they interact. Such diverse contexts and uncountable scenarios mean equifinality is the norm regarding the legal political incorporation of emigrants abroad.

Regarding elections in a destination country, foreign residents differ from nationals because they have carried their political stances and ideology across international borders and have undergone a political resocialization process in the destination country (White et al. 2008; Paul 2013; Finn 2020). International migrants have internalized various political attitudes, beliefs, and values based on political learning in more than one country under different political systems (Finn 2020). When states enfranchise immigrants, their political incorporation is different than when states add other minority groups into the demos. This is because migrants' legal status, home-country experiences, and holding a visa rather than nationality distinguishes them from native minorities (Ramakrishnan 2013: 36-37). While enfranchising foreign residents questions the nationality requirement for voting, enfranchising nonresident nationals disrupts the territorial (residence) aspect (Collyer 2014; Erdal 2016). Thereafter, these migrants have ties to or within at least two territories, meaning they "balance" more than one political community, from which they select how to be politically engaged in various ways in one or both locations (Erdal and Oeppen 2013).

Both emigrant and immigrant enfranchisement has occurred during established democracies (e.g., Austria, Italy, Japan), when countries were still new democracies (Mexico, Poland, Thailand), and in electoral autocracies (Belarus, Gabon, Kazakhstan), thus contrary to contemporary ideas that democracy is a driving force in enfranchising migrants, many regimes including hybrid and authoritarian regimes have enfranchised migrants (e.g., Collyer 2014a; Caramani and Grotz 2015).

Since migrant enfranchisement includes new voters into the demos, it falls under the larger umbrella of expanding voting rights, approaching more inclusive, or 'universal', suffrage. Suffrage is a measure of participation, a way in which individuals can voice political preferences to the state (Dahl 
1971). ${ }^{3}$ Whereas having rights determines who belongs to the political community, exercising these rights allow claims-making and participation in state decisions. The Chilean case underlines this important difference since the 1980 Constitution enfranchised foreign residents for national-level elections during dictatorship, so these individuals could not vote until the 1988 plebiscite (whose outcome curiously ended the dictator's reign). While granting migrant voting rights is a procedural step, exercising rights is a substantive step in approaching the democratic ideal of universal suffrage. ${ }^{4}$

\section{Migrant Enfranchisement in South America}

In South America, 10 of the 12 countries combine voting rights for both nonresident nationals as well as for foreign residents (GLOBALCIT 2019). ${ }^{5}$ Latin American migrant enfranchisement has been studied on its own as well as has served as comparisons in larger studies, for example explaining enfranchisement's various steps, trends, or theoretical reasons (Earnest 2008; Rhodes and Harutyunyan 2010; Escobar 2015, 2017; Lafleur 2015; Turcu and Urbatsch 2015; Palop-García and Pedroza 2018). The region comprises pioneers in migrant suffrage rights, dating back to immigrant voting in local-level elections in Buenos Aires in 1917, locally in Chile in 1925, ${ }^{6}$ and in both local and national (i.e., multilevel) elections in Uruguay in 1934 (Escobar 2015, 2017). After these early adopters, migrant enfranchisement continued to spread throughout the region. Many Latin American and Caribbean countries enfranchised emigrants abroad during democratization (Palop-García and Pedroza 2018).

${ }^{3}$ In Dahl (1971), voting is a measurement of participation, a dimension of polyarchy-which is not synonymous with democracy, but rather an imperfect approximation for the unachievable ideal of democracy. Nonetheless, I refer to polyarchy (specifically the right to vote, the eligibility for public office, and free and fair elections) since these aspects are relevant to the present analysis.

${ }^{4}$ It is not to say that turnout must involve the entire electorate in an election to be deemed universal suffrage; rather, exercising rights shows that existing voting rights are not just symbolic.

${ }^{5}$ As of March 2019, Uruguay has discussed but not extended the external vote to emigrants abroad and Suriname does not have external voting.

${ }^{6}$ While Chile's 1925 Constitution (Article 104) included some foreign residents as voters in municipal elections, they did not exercise the right to vote until 1935. An initial electoral law outlined voting regulations in 1931 — which also included women for the first time as voters-but a reform was passed in 1934 and applied in 1935 (Valenzuela E. 1995). 
While withholding rights may not be undemocratic, granting migrant voting rights is more democratic (Pedroza 2015). Democratic practices entail an outlet for individuals to convey their preferences to the state, in order for the latter to represent the former (Dahl 1971). South American countries used democratization or a return to democracy to reconnect with emigrants who left during non-democracy, as well as allowed those who had rights to finally use them in democratic elections (e.g., Doña and Finn unpublished). Democratization can relate to migrant enfranchisement (Lafleur 2015; Erlingsson and Tuman 2017), especially within a 'window of opportunity' following the democratic transition (Rhodes and Harutyunyan 2010).

Within Latin America's later wave of migrant enfranchisement, international factors have been important. When international standards permeate downwards and affect states' enfranchisement decisions, it falls into the global-norm hypothesis (Lafleur 2015; Turcu and Urbatsch 2015; Escobar 2017), meaning global standards or ideas influence national-level legislation. This is more fitting for migrant enfranchisement latecomers, such as Ecuador, but not early adopters such as Chile and Uruguay.

In South America from the 1920s through the 1980s, countries generally granted migrant voting rights under what Escobar (2015) calls non-democratic regimes led by "strongmen"; the exceptions are Chile in 1925 since it occurred in democracy and also in 1997 in Peru under strongman Fujimori. During ‘strongman' periods in Latin America, regimes have tended to be rightwing and offer rights to obtain symbolic support, legitimacy, or increase turnout (in fraudulent elections), thus most factors explaining enfranchisement were domestic (Escobar 2015). Such strongmen are not unusual in the region, even in democracy. Chile is no exception, given its hyperpresidentialist constitution favoring a stronger executive power over the legislative branch, including in migration laws and policy (Siavelis 2002; Stefoni 2011; Acosta 2018; Thayer 2019; Finn and Umpierrez de Reguero 2020).

Following these scholarly works, I focus on migrant suffrage through political regimes shifts, specifically between democracy, authoritarianism, and re-democratization, highlighting migrant voting rights' survival and expansion. Given South American states offer extensive migrant suffrage rights, combined with numerous experiences with authoritarianism, the region is ideal for analyzing unchanged migrant voting rights through shifting (non)democratic regimes. I specifically focus on Chile since the country politically incorporated foreign residents for national-level elections during dictatorship.

The manner and timing of extending suffrage to immigrants are important factors. There are two overarching enfranchisement alternatives: the bottom-up or top-down approach. The first stems 
from migrant communities demanding voting rights, such as how women suffrage spread. In the case of migrants, there were movements in Spain (in 2006) and in Buenos Aires (2011) demanding locallevel voting rights; however, in Latin America, most immigrants are not making these demands (Escobar 2015: 940, 943). Contrarily, the latter approach is when states offer voting rights: the supply exists regardless of demand. This has become more prolific for emigrant voting after the 1990s (Echeverría 2015a: 175). States may incorporate foreign residents into the demos via electoral reform and/or constitutional change, despite migrants not petitioning this right (e.g., in Chile). Top-down enfranchisement also occurs at a supranational level, for example the Maastricht Treaty in 1992 requires European Union (EU) states to grant local-level voting rights to other EU nationals living in the territory (i.e., local-level voting for EU passport holders); however, country-level timing and implementation have varied.

Regarding timing, Escobar (2015: 927) defines two main waves of immigrant enfranchisement in Latin America: first from the early twentieth century to the 1980s when "strongmen" in (non)democratic settings enfranchised this group for nationalist reasons (e.g., Chile). Early regional adopters of immigrant suffrage include Argentina in 1917 (only in Buenos Aires), Chile in 1925 in local-level elections (in democracy, but later expanding this right to the national level in 1980 under dictatorship), and Uruguay in 1934 in multilevel elections. Second was in the 1990s onwards, when Escobar (2015) finds that typically left-leaning governments in South America have granted migrant voting rights and started to differentiate between emigrant and immigrant suffrage; more international factors affected the decisions, such as globalization, international agreements on human rights, the notion of "universal citizenship," hope for reciprocity, and as a step toward regional market integration. Later adopters include Colombia (1991, multilevel), Peru (1997, local), Venezuela (1999, national level), Brazil (2001, multilevel), Ecuador (2008, multilevel), and Argentina (2011, local communities) (Escobar 2017). ${ }^{7}$

As compared to other South American states (namely, Argentina, Brazil, and Uruguay), Chile as an early adopter had a relatively low immigrant stock; within total population, it was around 1\% in 1970 and dropped to its lowest at $0.7 \%$ in 1982 during the dictatorship's restrictive migration period (Lara 2014: 81). Yet two of the main immigrant-receiving nations, Argentina and Uruguay, also

\footnotetext{
${ }^{7}$ In 1991 Bolivia adopted local-level suffrage, but did not implement these rights until 2013, when it was a right only for select foreigners.
} 
extended local-level voting rights around this time. ${ }^{8}$ At first glance, it is easy to highlight Chile's low immigration size as a non-barrier to enfranchisement. However, compared to its own domestic historic trends, the immigrant stock peaked in the twentieth century at $4.1 \%$ in 1907 then was slowly decreasing when the 1925 Constitution enfranchised certain foreign male residents for local-level voting (Acosta 2018; see Figure 1). Neighbors' inclusion of migrants in the demos affects other states' migrant enfranchisement (Earnest 2008), as is evident in this region in the first half of the twentieth century.

${ }^{8}$ In the City of Buenos Aires Law 1.240 of 1917 and in Uruguay's Constitution of 1934, Article 67 (Escobar 2017: 10). 
Figure 1 Chile's Immigrant Stock and Percentage of Total Population, Select Years 1875-2019

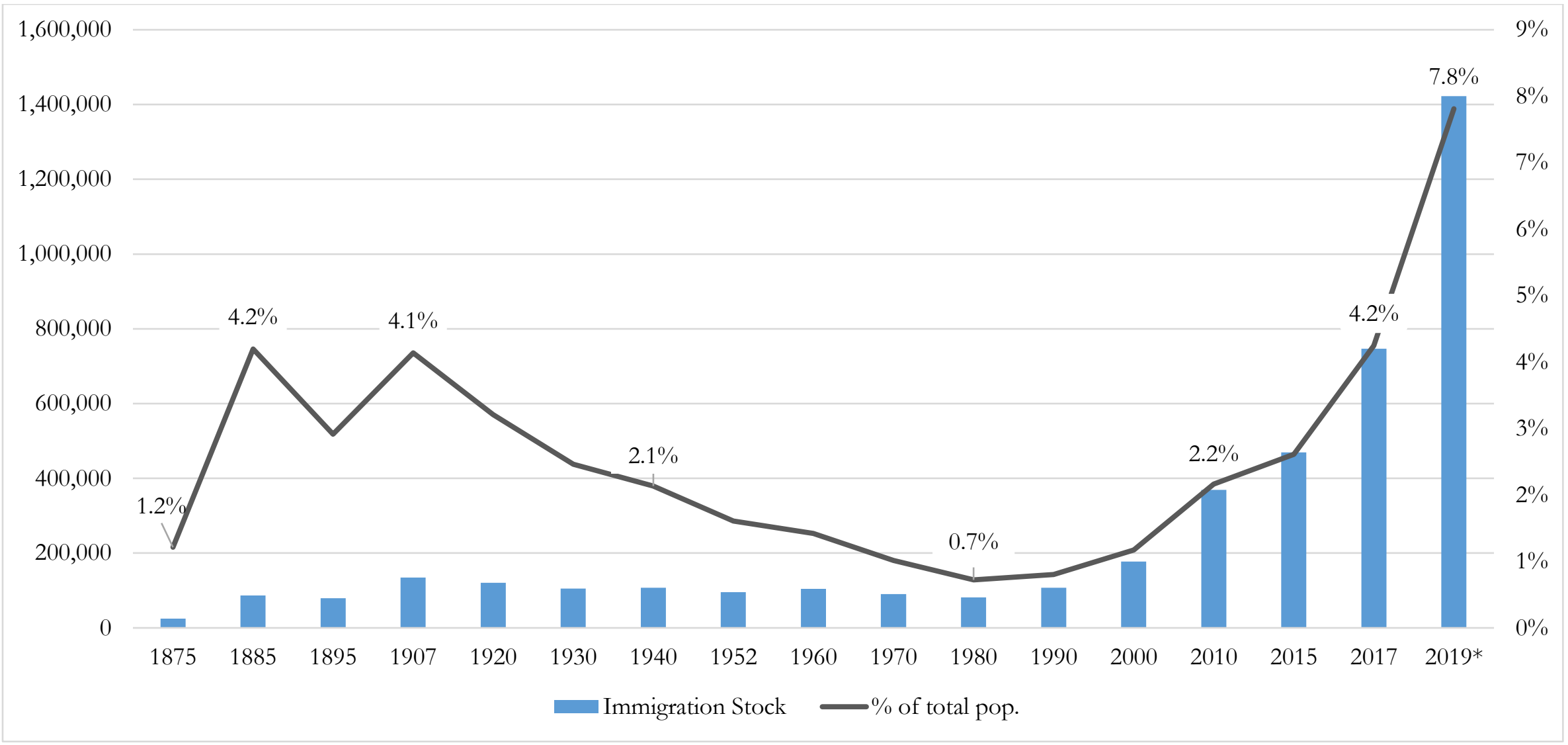

Source: Own elaboration based on data from INE-DEM (2019), INE (2019), and Censos de población y vivienda [Population and Housing Censuses] from Chile, select years between 1875 and 2017.

Notes: * Data in 2019 are estimates from INE (2019); after the last census in 2017, Chile began to cross census data with administrative records from the Department of Foreign Affairs and Migration (DEM) to obtain a more precise measure of the immigrant stock; the change in methodology explains the change from $4.2 \%$ in 2017 to $7.8 \%$ in the 2019 estimate. 
Chile used the top-down approach, given it first granted local-level immigrant voting rights in democracy in 1925, then extended them to the national level in 1980 under the military dictatorship of General Augusto Pinochet. Escobar (2015) classifies Chile in the first Latin American migrant suffrage wave, extending the right based on nationalist factors. However, "nationalist" factors are too generic to capture the country-specific context. Part of the motivation for more detailed analyses is to unpack why countries enfranchise migrants, in terms of the process and reasoning, as well as the political regime and timing of these long-lasting electoral changes.

\section{Case Selection and Method of Analysis}

I am interested in which migrants comprise a state's political community and why. States around the globe are politically incorporating migrants, but at different times, to different extents, for different reasons, and under different regimes. Historical comparisons dive deeper into the broad 'national' versus 'transnational' reasons by detailing why states enfranchise foreign residents. To better understand these reasons under varying political regimes, I conduct a case study of the immigrant enfranchisement process in national-level elections in Chile, drawing parallels to Ecuador and Uruguay. All three countries share the presence of universal foreign resident suffrage in national-level elections; however Uruguay has the strictest requirements for immigrants to obtain this right.

The present analysis builds off existent literature but differs in two main ways. First, it uses Escobar's $(2007 ; 2015 ; 2017)$ extensive cross-national research on migrant-state relations and political rights in Latin America as a starting point for a qualitative comparison of two cases. Instead of examining overall trends, reasonings, or impacts of migrants' political rights, I dive into an analysis searching for how and why states enfranchised immigrants at the national level. Second, by analyzing an early pioneer of extending non-discriminatory foreign resident voting rights, it shines light upon the misleading thought stream regarding the role of democratic ideals and international norms; the findings here remind us that the global-norm hypothesis applies only to latecomers in migrant suffrage rights. The main objective of an in-depth description, in terms of timing and political regimes, of the migrant enfranchisement process is to discuss why migrant voting rights can survive-or even expand-through (non)democratic political regime changes. 
Chile in 1980 is an extreme case of the migrant enfranchisement process. ${ }^{9}$ I select this case in an attempt to maximize the variance on the dimension of interest of comparing enfranchisement under (non)democratic regimes (Gerring 2007: 101, 104). This is appropriate for Chile due to the unusual circumstances during which the state first adopted migrant enfranchisement (in 1925, as a pioneer), expanded it (during a military dictatorship), and its expansive nature (eligibility for all adult migrants after a short residency period to vote at in multilevel elections). Moreover, rather than a specific hypothesis, I inquiry into the reasons for and process of enfranchisement.

To analyze the expansion of immigrant enfranchisement from local to national elections, I examine recorded (written) dialog from the Ortúzar Commission in 1974 (Historia de la Ley 2005). ${ }^{10}$ The Commission comprised a select group assigned to review the nationality and citizenship articles within the 1925 Constitution, in preparation for the eventual 1980 Constitution. These discussions are within the Historia de la Ley (2005) of Article 14 of the Republic of Chile's Political Constitution of 1980. The National Congressional Library, the Supreme Court, and the General Accounting Office collaborated to prepare this document. It contains sections of the conversations that occurred during the political sessions while the Commission members reviewed the previous constitution. I also use Articles 12 and 14 from Chile's 1980 Constitution, as well as academic references regarding context, enfranchisement, and historic to modern migration law.

\section{Expanding Foreign Residents' Rights in Dictatorship}

The coup d'état of Allende's administration resulted in a declared state of emergency and Pinochet's 17-year military dictatorship (1973-1990). Political parties had polarized to two extremes, dissolving the ideological center, which eliminated the possibility of forming coalitions necessary for reaching agreement (Bermeo 2003; Valenzuela 2003). To better set the context, Chile first gained independence in 1810 and the first constitution was in 1833. Political parties had started to form in between, starting with the Conservative, Radical, and Liberal party period from 1828-1891

\footnotetext{
${ }^{9}$ The entire immigrant enfranchisement process runs from 1925 to 1988 to cover the three steps of approval, regulation, and application (following Palop-García and Pedroza 2018) since 1988 was the first year in which foreign residents voted at the national level.

${ }^{10}$ The official name was the Commission of Studies for the New Political Constitution of the Republic of Chile (La Comisión de Estudios de la Nueva Constitución Política de la República de Chile), but is more commonly referred to as the Ortúzar Commission, given the last name of the group's leader.
} 
(Valenzuela 1995), meaning Chile had already experienced almost a century and a half of democracy. A tripolar division of left, center, and right had dominated the Chilean partisan system since the late 1820s and this deep-rooted system reemerged post-Pinochet (Scully 1996; Valenzuela 1995).

Pinochet knew that maintaining polarization would allow him to take advantage of the dire situation. According to Huneeus (2000), implementing economic and constitutional changes was part of a multidimensional plan to legitimize the regime (gaining admiration from some in the process), extend his rule, delay transition (i.e., continue the declared state of emergency), and centralize political power. Martínez and Díaz (1996) point out that changing the foundations of the political and socioeconomic systems may have been a standalone objective (also see Barros 2002). Being unable to single-handedly control all political players, Pinochet founded the secret police DINA ${ }^{11}$ to control the opposition, as well as spy on government employees in their private and professional lives (Huneeus 2000: 104, 160).

Part of the political overhaul to create change was wiping the slate clean: Pinochet eliminated other political parties and began a thorough revision of the constitution. The objective of reviewing the 1925 Constitution and implementing ('Chicago boys' technocrat style) free market economic change was to re-establish normalcy in politics and the economy, after it had been in dire straits prior to the coup (Huneeus 2000: 215-217). According to Bermeo (2003), society comprised 'ordinary people' who believed the coup saved Chile from communism, that the country was in a war against Marxism, and underestimated or ignored the abundant violence and human rights abuses. Although Pinochet aimed to settle the chaos, he used the situation of the war against Marxism and a state of emergency to maintain fear to be able to make significant institutional changes during this critical juncture in Chile.

Almost immediately following the 1973 coup, the Ortúzar Commission began to review the 1925 Constitution, which would contribute to produce Chile's 1980 Constitution. The lengthy process included extensive discussions during the Commission's sessions in 1974 that ended with the final wording for Article 12 (defining suffrage and who citizens are) and Article 14 (foreign resident voting),

${ }^{11}$ The DINA (Dirección de Inteligencia Nacional, or the National Intelligence Directorate) was the secret police in Pinochet's first years, which then changed to the CNI (Central Nacional de Informaciones, or the National Information Center) in 1977. These organizations, as well as Pinochet himself, were later tried in court for violating human rights, such as conducting torture (Huneeus 2000: 113, 163). 
which were approved in 1978 during the writing of what would become the 1980 Constitution. The Commission's purpose was to review specific constitutional contents, not write a new constitution.

\section{A Foreign Resident's Right Versus a National's Duty}

At the time, the Migration Law of 1975 regulated immigrant flows, which had been implemented earlier in Pinochet's regime from a national security perspective (Stefoni 2011); the law is still active as of August 2020 (see Finn and Umpierrez de Reguero 2020). Nonetheless, immigrant suffrage rights had not constitutionally changed since 1925 (but were accompanied by previously mentioned electoral laws from 1931 and 1934). The expansion of immigrant voting rights from local to national elections in the 1980 Constitution was not a drastic change but rather "institutional innovation" since the change expanded the status quo (Thelen 2003: 209). Since 1925, foreign voters had been able choose if they wanted to participate or abstain in municipality elections, I find that the Commission expanded this understanding to mean foreign resident voters should be able to choose whether they want to participate, or not, in all elections.

A critical political actor in forming this perspective regarding the right, not duty, to vote was Jaime Guzmán. Guzmán had led the Gremial movement and was close with Pinochet, writing numerous speeches for him and stating that this government could restore social peace (Huneeus 2000: 146). ${ }^{12}$ Guzmán was a vocal member of the Ortúzar Commission, taking suffrage stances opposing other Commission members-particularly contrasting Jorge Ovalle Quiroz, as well as the Commission's President, Enrique Ortúzar Escobar. The Commission members discussed immigrant voting as a right, not an obligation, and the dialogs express strong views regarding the appropriateness of mandatory voting.

Guzmán was the only one on the Commission who supports an optional voting system for all voters, whereas the other members posited it optional only for immigrant voters. Reviewing the Commission's debate in Historia de la Ley (2005: 35-38, 43-44), especially Ortúzar expressed that facultative (voluntary) voting would have grave consequences for social order, and it would be a mistake to interpret "the contemporary conception of what a free, open, and democratic society is" while being lax about the "weak sustaining bases" of such a society if the government allowed voters

\footnotetext{
${ }^{12}$ The Gremial movement was a Chilean political group located within higher education, based at the Catholic University (Universidad Católica), led by Jaime Guzmán, who maintained a "close relationship" with Pinochet, which served as the political backing for the movement (Huneeus 2000, 146).
} 
to choose to be interested, or not, in the electoral process. Ortúzar argues that the government must force people to vote, because if they had a choice, many would abstain-preferring instead a day of rest rather than making the "minimal sacrifice" of expressing their opinion via voting. He states that activists and those with strong interests would always vote, which would worsen the political divide when moderate voters abstain. As citizens lose interest in public matters, it would increase the chance for those "desiring the destruction of the institutional system" to succeed in doing so. Believing 'all members' must participate is not synonymous with universal suffrage goals, but it did reflect a large group since Chileans who turn 18 and who are free of convicted sentences and crimes; meeting such requirements also came with suffrage rights. ${ }^{13}$

Contrary to the mandatory voting discussion, the Commission views foreign resident voting as a right, not an obligation. They aim to constitutionally ensure that immigrant who met requirements will have the possibility to vote in the future but only if legislators decide to grant this right via electoral law (as Silva Bascuñán summarizes [Historia de la Ley 2005: 30])—thus highlighting the importance difference between the enfranchisement steps of enactment and regulation. Foreign residents, however, would not be able to run for elected office. Despite the Commission's stance that optional voting would make sense in a "purely aristocratic or elite society, but in no way in a democracy in which all its members are called to participate," they nonetheless decide that foreign residents should be allowed to opt in or out of being members of the electorate and choosing each time to vote or abstain in elections.

The Commission's stance endures, converted into Article 14 of the 1980 Constitution (DL. N3464), "Foreigners residing in Chile... may exercise suffrage rights in the cases and manner determined by law." Although the Commission wants to avoid the possibility that legislators or political parties could use immigrant enfranchisement as partisan leverage, their focus is on ensuring immigrant voting, if enacted, could never be constitutionally considered mandatory. The debate focuses on future interpretation of the constitution and who will meet requirements. They state that voting is not an inherent right, although express the stance that individual migrants will have the option (after 10 years, later reduced to 5) to choose, as the immigrants themselves see fit, to participate or not in the political community.

${ }^{13}$ After debate over if citizens should be 18 or 21 years old, the final decision (in Session 57 on December 5, 1987) favored 18 for citizens, and thus also for voting rights. 
The rights versus duties discussions have two repercussions for the voting system and personal freedoms. First, since the Commission, Chile changed to an optional voting system with automatic electoral registration in 2010, after experiencing declined turnout (Herrera and Navia unpublished) which did not destroy the institutional system. Turnout rates are indeed lower (Carlin 2006), which even Ortúzar's thinking predicted that fewer people would vote if it was voluntary. But based on the Commission's sessions, the debate was never about voting being optional or mandatory, but rather about how to control nationals to ensure they fulfil this obligation, considered as a "moral duty" - in other words, they extensively debated how to establish effective punishment those who do not vote (Historia de la Ley 2005: 35, 39-40, 42).

Second, the Commission's result (counterintuitively) increased foreign residents' personal freedoms while restricting that of nationals. As Commission member Enrique Evans de la Cuadra expresses, if Chile offers immigrants the chance to naturalize after a residence period, he sees no reason why the Constitution would not also grant suffrage rights to foreigners under certain conditions (Historia de la Ley 2005: 10). As Pedroza (2015) outlines, a country can include migrants in the demos via the traditional route of naturalization, or alternatively through enfranchising them. The Commission's view reflects the parity of the two routes since members expressed the possibility of optional voting after a residence period as just as logical as offering the possibility of naturalizing after a residence period. ${ }^{14}$ This created two routes to joining to the political community: naturalization would mean gaining the Chilean nationality and thereafter voting would be mandatory; ${ }^{15}$ alternatively, the Commission allowed non-naturalized immigrants also to join the Chilean political community and participate in elections only when they wanted:

\section{Immigration $\rightarrow$ Naturalization $\rightarrow$ Mandatory Voting for Nationals \\ 2. Immigration $\rightarrow$ Enfranchisement $\rightarrow$ Facultative Voting for Foreign Residents}

\footnotetext{
${ }^{14}$ The two routes are applicable only to first-generation immigrants since Chile has ius soli laws: children are born into a citizenship, meaning nationality is a non-voluntary membership.

${ }^{15}$ Various reasons exist as to why people would prefer not to naturalize in a country, e.g., it may change legal (economic, social, or political) rights in the origin country; they may feel the costs outweigh the additional benefits; they may already have more than one nationality or are not allowed to have another; others may lack the resources to apply or not meet requirements.
} 
The second route gave immigrants extensive personal freedom to choose the extent to which they participate in the destination country, more freedom than Chilean voters who must vote once they meet requirements. Allowing such agency and autonomy leaves political integration up to individuals. In sum, immigrants who already resided in Chile received more extensive voting rights and greater personal freedom in exercising this right, as compared to other voters. However, this strangely occurred during a restrictive period in Chile's migratory legislative history that deported many foreigners and discouraged others from entering the country, framing them as threats to society, the regime, and state security (Lara 2014: 62, 81, 90). ${ }^{16}$

In sum, the expansive (and unintentional) view of existent immigrants' personal freedoms in deciding political integration starkly contrasts with the Commission members' rigid view for the Constitution ensuring Chileans of voting age comply with the 'duty' to vote. Discussing constitutional rights, the Commission established a view that, despite being capable of exercising suffrage in multilevel elections, nationals and foreigners had fundamentally different relationships with the state since the state had different expectations for these individuals. Commission members stressed that immigrant suffrage was (and should be) a right, not an obligation. According to Committee members (except Guzmán), it would have been an extraordinarily serious matter if the Constitution had allowed Chileans a choice in the matter since that would recognize that they could be "indifferent" to their 'own society' and country's future.

\section{New Insights from the Chilean Case}

Analyzing immigrant suffrage rights, Chile is a revealing case that quakes the notion and rhetoric that migrant enfranchisement is naturally democratic or influenced by international forces. Extreme shifts in political regimes and power not only saw the maintenance of foreign resident suffrage, but also the extension of it. Here I highlight four new insights based on the Chilean case.

First, immigrant national-level enfranchisement was not a stand-alone discussion or legal change. As Durán and Thayer (2017) highlight, Chile’s nineteenth-century migration-related laws focused on encouraging certain inflows, whereas progressively incorporating select immigrants into

${ }^{16}$ The military dictatorship had strict control over mobility of all persons, Chileans and foreigners alike, who were entering or leaving the territory (DL 2460 of 1979), and expelled individuals post 24hour notification (see Lara 2014: 87-88). 
legislation have roots stemming from the early twentieth century. Enfranchisement in the 1980 Constitution was a very minor change amongst a complete constitutional revamp. These drawn-out constitutional changes were part of Pinochet's lengthy plan to centralize power and delay democratic transition.

Second, given the context, migrant enfranchisement was far from trying to achieve inclusion or democratic ideals (such as universal suffrage), nor was it a human right. Occurring during a state of emergency and at the start of a military dictatorship, the Ortúzar Commission members (ironically) discussed 'democratic ideals.' They felt strongly about nationals' roles as stakeholders in the country's future and their obligation to exercise suffrage, demonstrated by rigorously supporting mandatory voting systems (Historia de la Ley 2005). Moreover, free and fair electoral process would not be held until a decade and a half later in 1988, a plebiscite that ended the military dictatorship. This leads me to highlight that although Chile was an early pioneer in local-level immigrant voting rights in 1925, when Chile enfranchised immigrants for national-level elections in the 1980 Constitution, it was a far cry from any democratic trend or desire for human rights or inclusion.

Third, the state allowed foreign residents to take an interest in politics or become integrated to their own desired extent within the political community, in various ways, except running for public office. Simultaneously, it strictly forbade Chilean voters to be indifferent about politics, seeking to punish those who failed complete their 'moral duty' to vote. Although Chile adopted immigrant voting rights without human rights in mind, the dialog behind the legislation gave foreign residents more personal liberty (and less coercive requirements) than they provided for nationals. However, freedom to choose was for a small select group of existent immigrants during a restrictive migration legislation period during which the state discouraged newcomers and expelled foreigners and Chileans alike (Lara 2014).

Fourth and finally, the size of the immigrant population hardly played a role in the process of expanding such suffrage in this case. Immigration size helps to explain why the government could enact it without opposition, not why they did. An authoritarian regime holding political power was a stronger deterrent from public backlash; the Commission or government had no need to justify their reasons or decisions to voters-but they also did not have to expand foreign residents' suffrage rights, either. In other words, the context and constitutional dialog proceeding voting rights extension leads me to conclude that the actual number of immigrants had very little to do with enfranchising this group. 
During the constitutional commission sessions, the members' concerns and debates revolved around the exact grammatical wording of voting rights, its non-obligatory nature, the act of electing a representative versus being elected, and which requirements immigrants must meet before voting. The Commission discussed which, when, and legally how immigrants will vote at the national level, never if immigrants will vote in Chile. Thus, the historical inclusion of foreign residents in the demos for locallevel elections in the 1925 Constitution was much more important than other factors in explaining the enfranchisement expansion. Once again, Brubaker's (1992) insight on the importance of individuals' historical understanding of who comprises the demos begins path dependence on migrant rights. In Chile, who could partake in the political community in 1925 strongly affected the discussions in the 1970s about extending migrant voting, which then resulted in expanding foreign resident voting to the national level in 1980, which has remained to present (as of 2019). This configurational sequence of implementation, expansion, and survival of migrant voting rights occurred regardless of drastic changes in political regimes, fluctuating from democracy to authoritarianism and a return to democracy.

\section{Conclusion}

Since democracy is not a necessary or sufficient condition for extending nor maintaining foreign residents' voting rights, contrary to contemporary vernacular around such suffrage, it is not by default a democratic phenomenon. Furthermore, immigrant suffrage rights have shown durability through political regime shifts. This includes during transitions from democracy to authoritarianism and re-democratization (e.g., in Chile and Uruguay). These processes show that foreign residents' voting rights, once established, can endure extreme shifts in (non)democratic political regimes.

Foreign residents who maintain (or gain) suffrage rights under nondemocratic governments comprises new evidence that strengthens Brubaker's (1992) insight that historical conceptions of the demos will have long-lasting effects. These original notions of foreign residents' roles within the political community were evident in Chile's constitutional discussion in the 1970s regarding expanding foreign resident voting from the local level (from the 1925 Constitution during democracy) to the national level (in the 1980 Constitution during non-democracy). This continuity suggests path dependency for certain migrants' rights to endure, despite fluctuating ideology and regime types. Analyzing the Ortúzar Commission members' extensive session debates on nationals, aliens, and suffrage, they revolved around which foreigners will have the right to vote under which rules, rather 
than if foreigners will vote. After a designated residence period, the state saw naturalization and enfranchisement as equally logical routes to joining the demos, leaving the choice up to the immigrants themselves. They discussed legal phrasing and logistics, as well as emphasized the difference between foreign residents electing representatives versus being elected as a representative. Immigrant suffrage was explicitly to be a right-never an obligation, as it was for nationals—although not an inherent human right.

\section{Acknowledgements}

Many thanks to Claudio Fuentes, Felipe Solaris-Pérez, Sebastián Umpierrez de Reguero, and Jorge Vásquez for insightful comments and additional sources. I also extend my gratitude to Cristina Escobar for generously sharing additional historical research with me.

\section{References}

Acosta, D. (2018) The National and the Foreigner in South America: 200 Years of Migration and Citizenship Law. Cambridge University Press.

Arrighi, J. and R. Bauböck (2017) A Multilevel Puzzle: Migrants’ Voting Rights in National and Local Elections. European Journal of Political Research 56(3), 619-639.

Barros, R. (2002) Constitutionalism and Dictatorship: Pinochet, the Junta, and the 1980 Constitution (Vol. 4). Cambridge University Press.

Bauböck, R. (2005) Expansive Citizenship: Voting beyond Territory and Membership. Political Science and Politics 38(4), 683-687.

Bauböck, R. (2012) Migration and Citizenship: Normative Debates. In M. R. Rosenblum and D. J. Tichenor (Eds.) Oxford Handbook of the Politics of International Migration. Oxford, New York: Oxford University Press.

Bauböck, R. (2015) Morphing the Demos into the Right Shape: Normative principles for enfranchising resident aliens and expatriate citizens. Democratization, 22(5), 820-839.

Beckman, L. (2008) Who Should Vote? Conceptualizing Universal Suffrage in Studies of Democracy. Democratization, 15(1), 29-48.

Bermeo, N. (2003) Ordinary People in Extraordinary Times: The Citizenry and the Breakdown of Democracy. Princeton: Princeton University Press. 
Brubaker, R. (1992) Citizenship and Nationhood in France and Germany. Cambridge, MA: Harvard University Press.

Caramani, D. and F. Grotz (2015) Beyond Citizenship and Residence? Exploring the Extension of Voting Rights in the Age of Globalization. Democratization 22(5), 799-819.

Carlin, R. (2006) The Decline of Citizen Participation in Electoral Politics in Post-Authoritarian Chile. Democratization 13(4): 632-651.

Censo de población [Population Census] (1875-1940) Santiago, Chile: National Institute of Statistics. https://www.ine.cl/estadisticas/sociales/censos-de-poblacion-y-vivienda/poblacion-yvivienda.

Censo de población y vivienda [Population and Housing Census] (1952-2017). Instituto Nacional de $\begin{array}{llll}\text { Estadísticas } \quad \text { Institute of } & \text { Stational }\end{array}$ https://www.ine.cl/estadisticas/sociales/censos-de-poblacion-y-vivienda/poblacion-yvivienda.

Chan, C. and M. Montt Strabucchi (2020) Many-Faced Orientalism: Racism and xenophobia in a time of the novel coronavirus in Chile. Asian Ethnicity (online).

Collyer, M. (2014) A Geography of Extra-Territorial Citizenship: Explanations of External Voting. Migration Studies, 2(1), 55-72.

Dahl, R. (1971) Polyarchy: Participation and Opposition. New Haven, CT: Yale University Press.

Doña, C. R. and V. Finn (unpublished) Multilevel Narratives and Emigration Policies: Insights from South America, 2000-2017.

Durán Migliardi, C., and L. E. Thayer (2017) Los migrantes frente a la ley: Continuidades y rupturas en la legislación migratoria del Estado chileno (1824-1975) [Migrants facing the Law: Continuities and breakdowns in migratory legislation in the Chilean state (1824-1975)]. Historia 396, 7(2): 429-361.

Earnest, D. C. (2006) Neither Citizen nor Stranger: Why States Enfranchise Resident Aliens. World Politics 58(2), 242-275.

Earnest, D. C. (2008) Old Nations, New Voters: Nationalism, Transnationalism, and Democracy in the Era of Global Migration. Albany: State University of New York Press.

Echeverría, G. (2015a) Between Territoriality, Identity, and Politics: The External Vote of Ecuadorians in Madrid. In M. C. La Barbera (Ed.) Identity and Migration in Europe: Multidisciplinary Perspectives. Springer International Publishing. 
Echeverría, G. (2015b) Access to Electoral Rights Chile. EUDO Citizenship Observatory, RSCAS/EUDO-CIT-ER 2015/20. Robert Schuman Centre for Advanced Studies, Badia Fiesolana, San Domenico di Fiesole, Italy.

Erdal, M. B. (2016) Juxtaposing Pakistani Diaspora Policy with Migrants' Transnational Citizenship Practices. Geoforum 76: 1-10.

Erdal, M. B., and C. Oeppen (2013) Migrant Balancing Acts: Understanding the Interactions Between Integration and Transnationalism. Journal of Ethnic and Migration Studies, 39 (6): 867-884.

Erlingsson, H., and J. P. Tuman (2017) External Voting Rights in Latin America and the Caribbean: The influence of remittances, globalization, and partisan control. Latin American Policy, 8(2), 295-312.

Escobar, C. (2007) Extraterritorial Political Rights and Dual Citizenship in Latin America. Latin American Research Review, 42(3), 43-75.

Escobar, C. (2015) Immigrant Enfranchisement in Latin America: From Strongmen to Universal Citizenship. Democratization 22 (5): 927-950.

Escobar, C. (2017) Migration and Franchise Expansion in Latin America. Comparative Report 2017/01, Global Citizenship Observatory and the Robert Schuman Centre for Advanced Studies, European University Institute, San Domenico di Fiesole, Italy.

Finn, V. (2019) Entre el individuo y el Estado: Burocracia pre- y post-migratoria [The Individual versus the State: Pre- and Post-Migration Bureaucracy]. REMHU Revista Interdisciplinar da Mobilidade Humana, 26(56), 159-178.

Finn, V. (2020) Migrant Voting: Here, There, in Both, or Nowhere. Citizenship Studies 24(6): 730-750. doi.org/10.1080/13621025.2020.1745154

Finn, V., and Umpierrez de Reguero, S. (2020) Inclusive Language for Exclusive Policies: Restrictive Migration Governance in Chile, 2018. Latin American Policy, 11(1): 42-61. https://doi.org/10.1111/lamp.12176.

Gerring, J. (2007) Case Study Research: Principles and Practices. Cambridge: Cambridge University Press.

GLOBALCIT (2019) ELECLAW Indicators. Version 5.1, San Domenico di Fiesole: European University Institute. https://globalcit.eu/electoral-law-indicators/.

Hawkins, K.A. \& Rovira Kaltwasser, C. (2017) The Ideational Approach to Populism. Latin American Research Review 52(4): 513-528.

Herrera, M. and P. Navia (unpublished) The Effect of Enfranchised Migrants on Electoral Turnout: Evidence from Chile in 2012. 
Historia de la Ley (2005) Constitución política de la República de Chile de 1980, Historia de la ley, Artículo 14 [The Republic of Chile's Political Constitution of 1980, History of the law, Article 14]. Prepared by the National Congressional Library, Supreme Court, and the General Accounting Office, Chile.

Huneeus, C. (2000) El Régimen de Pinochet [Pinochet's Regime]. Santiago, Chile: Sudamericana.

IDEA (2018) Voting from Abroad Database. www.idea.int/data-tools/data/voting-abroad.

INE: Instituto Nacional de Estadísticas [National Institute of Statistics] (2019) Estimaciones y proyecciones de la población de Chile 2002-2035. Totales regionales, población urbana y rural. Síntesis de resultados. Instituto nacional de estadísticas [Estimates and Projections of the Population in Chile, 2002-2035. Synthesis of Results]. Santiago, Chile: INE. June 2019.

INE-DEM [National Institute of Statistics-Department of Foreign Affairs and Migration]. (2019) Estimación de personas extranjeras residentes en Chile al 31 de diciembre 2018. Informe metodológico [Estimates of Foreign Residents in Chile, December 31, 2018: Methodological report]. Santiago, Chile: INE, DEM. February 2019.

Lafleur, J. M. (2015) The Enfranchisement of Citizens Abroad: Variations and Explanations. Democratization 22 (5), 840-860.

Landsberger, H. A. and T. McDaniel (1976) Hypermobilization in Chile, 1970-1973, World Politics 28(4): 502-541.

Lara Escalona, M. D. (2014) Evolución de la legislación migratoria en Chile, claves para una lectura (1824-2013) [Evolution of Migratory Legislation in Chile: Key overview 1824-2013]. Revista de Historia del Derecho, 47: 59-104.

López-Guerra, C. (2005) Should Expatriates Vote? Journal of Political Philosophy, 13(2), 216-234.

Martínez, J., and A. Díaz (1996) Chile: The Great Transformation. Washington, DC: Brookings Institution.

Millar Carvacho, R. (1981) La elección presidencial de 1920 [The 1920 Presidential Election]. Santiago, Chile: Editorial Universitaria.

Mollenkopf, J. (2013) Dimensions of Immigrant Political Incorporation. In J. Hochschild, J. Chattopadhyay, C. Gay, and M. Jones-Correa (Eds.) Outsiders No More? Models of Immigrant Political Incorporation. Oxford University Press.

Owen, D. (2012) Constituting the Polity, Constituting the Demos: On the Place of the All Affected Interests Principle in Democratic Theory and in Resolving the Democratic Boundary Problem. Ethics and Global Affairs 5(3), 129-152. 
Palop-García, P., and L. Pedroza (2018) Passed, regulated, or applied? The different stages of emigrant enfranchisement in Latin America and the Caribbean. Democratization 26(3), 401-421.

Paul, R. (2013) Space, the Final Frontier of Political Socialisation Research: Geopolitical contexts, migrant resocialisation and political remittances. In Growing into Politics: Contexts and timing of political socialisation, 183-216.

Pedroza, L. (2015). The Democratic Potential of Enfranchising Resident Migrants. International Migration, 53(3), 22-35.

Pedroza, L. (2019) Citizenship Beyond Nationality: Immigrants' Right to Vote Across the World. Philadelphia, PA: University of Pennsylvania Press.

Ramakrishnan, S. K. (2013) Incorporation versus Assimilation: The Need for Conceptual Differentiation. In J. Hochschild, J. Chattopadhyay, C. Gay, and M. Jones-Correa (Eds.) Outsiders No More? Models of Immigrant Political Incorporation. Oxford University Press.

Rhodes, S., and A. Harutyunyan (2010) Extending Citizenship to Emigrants: Democratic Contestation and a New Global Norm. International Political Science Review 31(4), 470-493.

Scully, T. R. (1996) La Reconstitución de la Política de Partidos en Chile [The Recontstruction of Political Parties in Chile]. In Mainwaring, S. (Ed.) La Construcción de Instituciones Democráticas: Sistema de Partidos en América Latina [The Construction of Democratic Institutions: Party systems in Latin America]. Santiago, Chile: CIEPLAN, pp. 83-112.

Shapiro, I. (2003) The Moral Foundations of Politics. New Haven: Yale University Press.

Siavelis, P. (2002) Exaggerated Presidentialism and Moderate Presidents: Executive-legislative relations in Chile. In Morgenstern, S. and B. Nacif (Eds.) Legislative Politics in Latin America, pp. 79-113. Cambridge: Cambridge University Press.

Stefoni, C. (2011) Ley y política migratoria en Chile. La ambivalencia en la comprensión del migrante [Migration law and policy in Chile: Ambivalence in understanding the migrant]. In B. FeldmanBianco, L. Rivera, S. Carolina, et al. (Eds.) La construcción social del sujeto migrante en América Latina Prácticas, representaciones y categorias [The Social Construction of the Migrant Subject in Latin America], pp. 59-87. Quito: Ediciones FLACSO Ecuador-CLACSO-Universidad Alberto Hurtado.

Stuhldreher, A. (2012) El sufragio transnacional: una aproximación al caso de Uruguay [Transnational Suffrage: An approximation of the Uruguayan case]. Estudios Internacionales, 172, 7-28.

Thayer, L. E. (2019) Causas y consecuencias de la irregularidad migratoria [The Causes and Consequences of Irregular Migration]. In N. Rojas Pedemonte and J. T. Vicuña SJ (Eds.) 
Migración en Chile [Migration in Chile], pp. 297-334. Santiago, Chile: Servicio Jesuita a Migrantes.

Thelen, K. (2003) How Institutions Evolve: Insights from Comparative Historical Analysis. In J. Mahoney and D. Rueschemeyer (Eds.) Comparative Historical Analysis in the Social Sciences. New York: Cambridge University Press.

Turcu, A., and R. Urbatsch (2014) Diffusion of Diaspora Enfranchisement Norms: A Multinational Study. Comparative Political Studies, 1-31.

Valenzuela, A. (2003) El quiebre de la democracia en Chile [The Breakdown of Democracy in Chile]. Santiago, Chile: Ediciones Universidad Diego Portales.

Valenzuela, E. M. (1995) Catolicismo, Anticlericalismo y la extensión del sufragio a la mujer en Chile [Catholicism, Anticlericalism, and Extending Suffrage to Women in Chile]. Estudios Públicos 58 (otoño 1995): 137-197.

Valenzuela, S. J. (1995) Orígenes y transformaciones del sistema de partidos en Chile [Origins and Transformations in the Party System in Chile]. Estudios Públicos, 58: 5-80.

Whelan, F. G. (1983) Prologue: Democratic Theory and the Boundary Problem. Nomos, 25, 13-47.

White, S., N. Nevitte, A. Blais, E. Gidengil, and P. Fournier (2008) The Political Resocialization of Immigrants: Resistance or Lifelong Learning? Political Research Quarterly, 61(2): 268-281. 